\title{
Perancangan Sistem Informasi Pendaftaran Rawat Jalan Menggunakan TOGAF ADM dan Kombinasi COBIT 5
}

\author{
Herza Martianda ${ }^{1}$, Sudin Saepudin ${ }^{2}$ \\ 1,2Program Studi Sistem Informasi, Universitas Nusa Putra, Sukabumi, Indonesia \\ Email: herza.martiandasi17@nusaputra.ac.id
}

\begin{abstract}
$\boldsymbol{A B S T R A C T}$
Bhayangkara Setukpa Hospital Lemdiklat Polri is one of several hospitals located in Sukabumi. Hospitals provide health services, one of which is outpatient registration services. In his service performance Rs. Bhayangkara Setukpa Lemdiklat Polri is still not optimal, in 2017 to 2019 there was an increase in the number of outpatient visits by 50\% and in 2020 the decline reached $27 \%$. The current outpatient registration information system is still offline and has a long registration service time because the patient must fill out a form first, while the registration officer is only guarded by two people without being supported by the speed of the registration information system that can be accessed by the patient. Hospitals do not yet have an alternativeregistration online, while in this digital era, hospital services need to be improved by implementing Enterprise Architecture (EA) using TOGAF ADM (The Open Group Architecture Framework. Architecture Development Method) and the Combination of COBIT 5 (Control Objective for Information and Related Technology). TOGAF ADM can define the stages of information architecture design and need COBIT 5 support to carry out the stages. E $A$ is useful for fulfilling future business processes. EA design is the right solution in supporting the organization of a business. Therefore, the authors design to support anregistration information system online that is integrated in the process of running the right business at the Hospital. The result of the TOGAF ADM framework and the COBIT 5 Combination is a blue print for EA design in the form of recommendations for IT HR Recruitment, Outpatient Registration Information System Design, Employee Training, and Outpatient Registration Marketing Innovations.
\end{abstract}

Keywords: Outpatient Registration, Information System, EA, TOGAF ADM, COBIT 5

\begin{abstract}
ABSTRAK
RS. Bhayangkara Setukpa Lemdiklat Polri adalah salah satu dari beberapa rumah sakit yang berada di Sukabumi. Rumah sakit menyediakan pelayanan kesehatan, yang salah satunya yaitu pelayanan pendaftaran rawat jalan. Dalam kinerja pelayanan nya Rs. Bhayangkara Setukpa Lemdiklat Polri masih belum optimal, pada tahun 2017 s/d 2019 terjadi peningkatan jumlah kunjungan rawat jalan sebesar 50\% dan pada tahun 2020 terjadinya penurunan mencapai $27 \%$. Sistem informasi pendaftaran rawat jalan yang ada saat ini masih bersifat offline dan lamanya waktu pelayanan pendaftaran karena pasien harus mengisi formulir terlebih dahulu, sedangkan petugas pendaftaran hanya dijaga oleh dua orang saja tanpa didukung kecepatan sistem informasi pendaftaran yang dapat diakses oleh pasien. Rumah Sakit belum mempunyai alternatif pendaftaran yang bersifat online, sedangkan di era yang digital ini pelayanan di Rumah Sakit perlu ditingkatkan dengan menerapkan Enterprise Architecture (EA) menggunakan TOGAF ADM (The Open Group Architecture Framework. Architecture Development Method) dan Kombinasi COBIT 5 (Control Objective for Information and Related Technology). TOGAF ADM dapat mendefinisikan tahapan perancangan arsitektur informasi dan perlu dukungan COBIT 5 untuk melaksanakan tahapannya. Ea berguna untuk memenuhi proses bisnis kedepannya. Perancangan EA merupakan solusi yang tepat dalam mendukung organisasi suatu bisnis. Oleh karena itu penulis melakukan perancangan untuk mendukung sistem informasi pendaftaran secara online yang terintegrasi dalam proses menjalankan bisnis yang tepat di Rumah Sakit. Hasil dari kerangka kerja TOGAF ADM dan Kombinasi COBIT 5 adalah blue print perancangan EA berupa rekomendasi Perekrutan SDM IT, Perancangan Sistem Informasi Pendaftaran Rawat Jalan, Pelatihan Karyawan, dan Inovasi Pemasaran Pendaftaran Rawat Jalan.
\end{abstract}

Kata Kunci: Pendaftaran Rawat Jalan, Sistem Informasi, EA, TOGAF ADM, COBIT 5.

\section{Pendahuluan}

Sistem informasi adalah sistem yang menyediakan informasi untuk memutuskan suatu keputusan dan menjalankan kegiatan secara operasional dalam organisasi dan memperoleh suatu 
keunggulan secara kompetitif[1]. Enterprise architecture merupakan gambaran atau cetak biru (blue print) suatu organisasi yang selaras dengan visi dan misi organisasi (business architecture) dengan teknologi informasi.Terdiri atas data, aplikasi, dan teknologi[2].

Menurut Keputusan Menteri Kesehatan Republik Indonesia No. 340/MENKES/PER/III/2010 "Rumah sakit adalah institusi pelayanan kesehatan yang menyelenggarakan pelayanan kesehatan perorangan secara paripurna yang menyediakan pelayanan rawat inap, rawat jalan dan gawat darurat'[3]. Rumah Sakit diperlukan untuk menawarkan jenis bantuan yang berkualitas sesuai dengan prinsip yang ditetapkan dan dapat mencapai semua lapisan masyarakat[4].

RS. Bhayangkara Setukpa Lemdiklat Polri yang ada di Jl. Aminta Azmali No. 59A, Kecamatan Gunung Puyuh Kota Sukabumi dalam kinerja pelayanan nya masih belum optimal. Hal ini bisa dilihat dalam gambar grafik berikut ini :

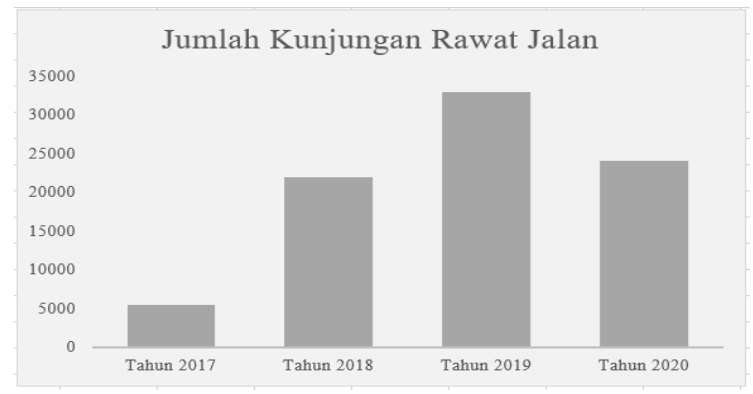

Gambar 1. Jumlah Kunjungan Rawat Jalan

Pada tahun 2017 s/d 2019 terjadi peningkatan jumlah kunjungan rawat jalan sebesar 50\% dan pada tahun 2020 terjadinya penurunan mencapai 27\%. Pelayanan di rumah sakit merupakan salah satu aktivitas yang penting bagi pasien, terutama di pelayanan pendaftaran. Seringkali pelayanan pendaftaran memakan waktu yang lama, sedangkan alur di rumah sakit bukan hanya sampai pendaftaran saja. Pasien harus mendaftar terlebih dahulu untuk melakukan berobat jalan, pemeriksaan fisik pasien oleh perawat, diagnosa penyakit, sampai pengambilan obat dan melakukan transaksi apalagi bagi rumah sakit yang belum sepenuhnya menerapkan sistem informasi baik online maupun offline. Untuk mengatasi permasalahan tersebut rumah sakit perlu memulai merencanakan enterprise architecture untuk mendukung sistem informasi yang terintegrasi dengan menjalankan langkah-langkan berdasarkan kerangka kerja TOGAF ADM dan Kombinasi COBIT 5 sebagai rekomendasi tata kelola teknologi di Rumah Sakit.

\section{Kerangka Teoritis}

\section{Penelitian Terkait}

Penelitian terkait dilakukan oleh Suryadi dan Johanes Fernendes Andry dengan judul Perancangan Enterprise Architecture Menggunakan TOGAF Architecture Development Method (Studi Kasus: Yakuza GYM Jakarta Barat)[5]. Penelitian selanjutnya oleh Annisah dengan judul Usulan Perencanaan Smart City : Smart Governance Pemerintah Daerah Kabupaten Mukomuko[6]. Penelitian Ade Supriatna dengan judul Analisa Penerapan TOGAF Dan COBIT Dalam Tata Kelola Teknologi Informasi Sebagai Usulan Pada Kementerian Energi Dan Sumber Daya Mineral[7].

\section{TOGAF ADM (The Open Group Architecture Framework Architecture Development Method)}

TOGAF adalah metodologi \& kerangka kerja arsitektur perusahaan yang telah terbukti digunakan oleh organisasi terkemuka dunia untuk meningkatkan efisiensi bisnis. Standar arsitektur perusahaan yang paling menonjol dan andal, memastikan standar, metode, dan komunikasi yang 
konsisten di antara para profesional arsitektur perusahaan. Sedangkan ADM adalah metode berulang, di seluruh proses, di antara fase dan di dalam fase[8].

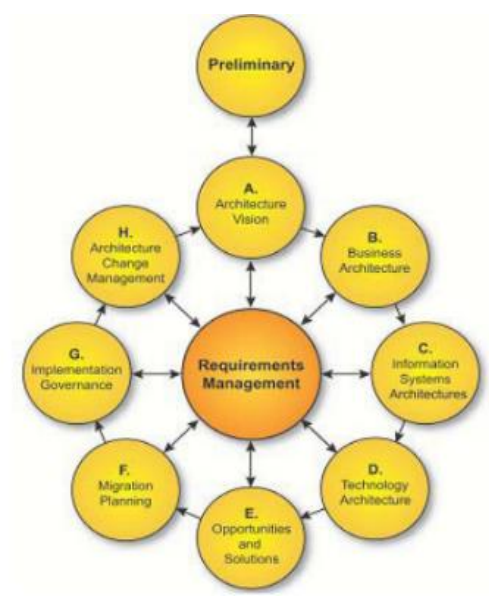

\section{Gambar 2. TOGAF ADM}

\section{COBIT 5 (Control Objective for Information and Related Technology)}

COBIT 5 mekanisme untuk menerjemahkan kebutuhan pemangku kepentingan menjadi tujuan perusahaan yang spesifik, dapat ditindaklanjuti dan disesuaikan, tujuan terkait TI, dan tujuan yang memungkinkan. Terjemahan ini memungkinkan penetapan tujuan spesifik di setiap tingkat dan di setiap area perusahaan untuk mendukung tujuan keseluruhan dan persyaratan pemangku kepentingan[9].

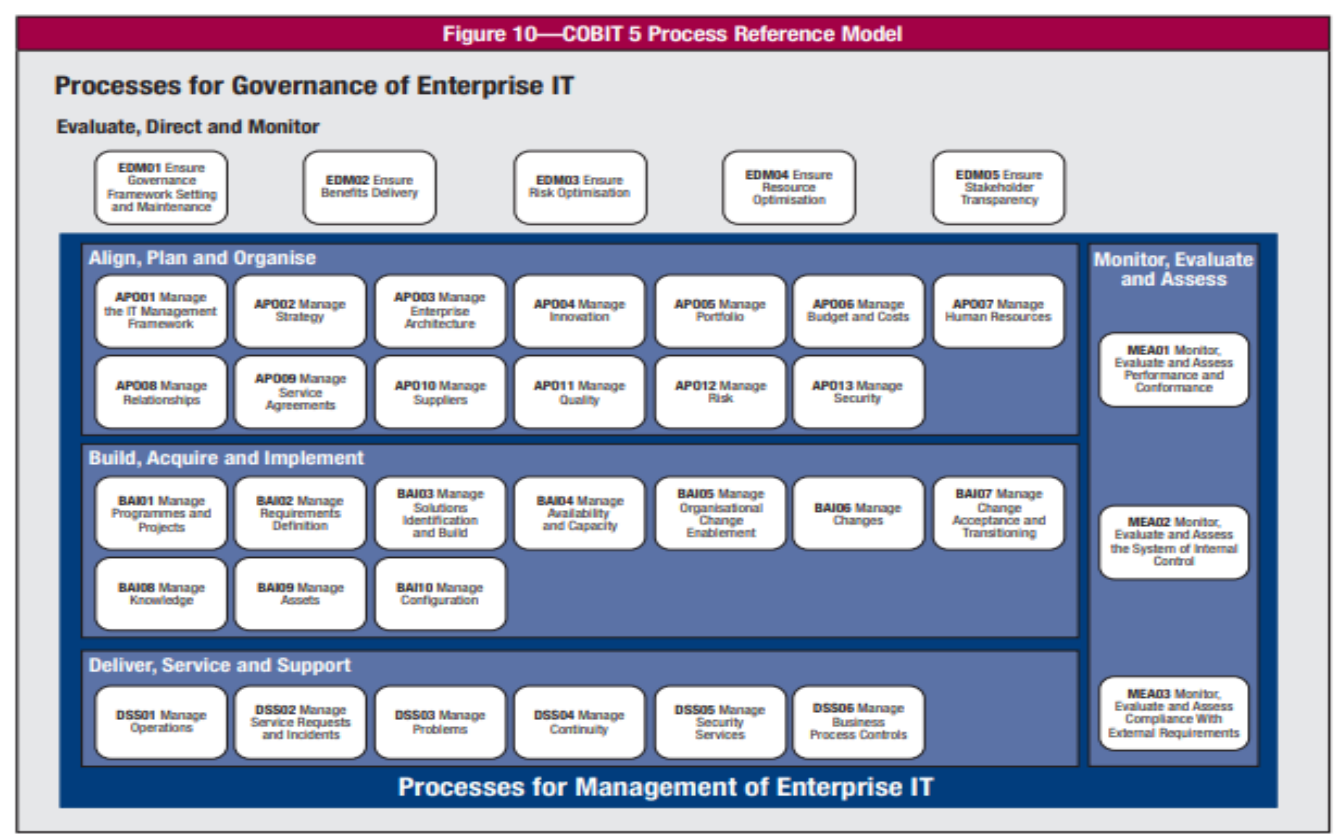

Gambar 3. COBIT 5 Process Capability 


\section{Metode \\ Tahap Penelitian}

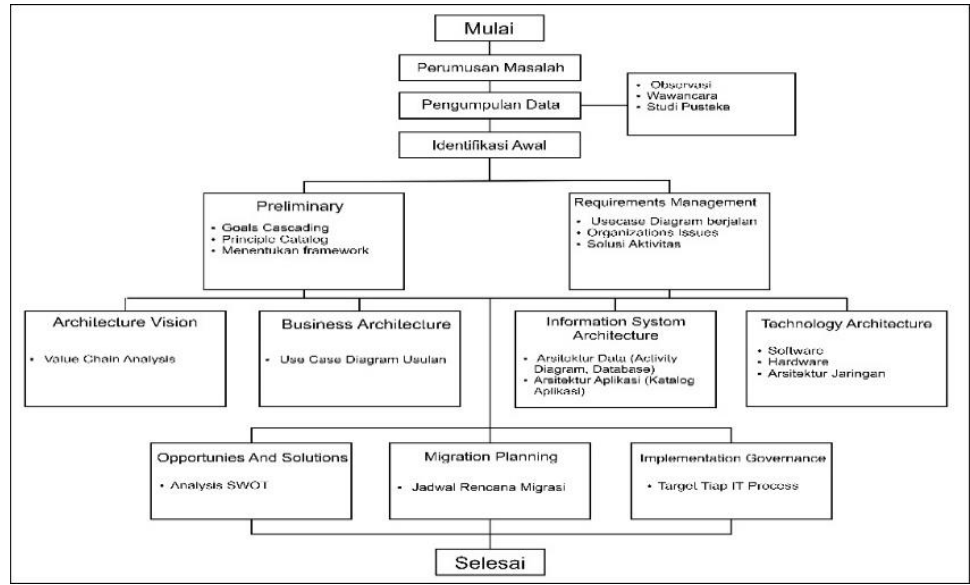

Gambar 4. Tahapan Penelitian

\section{Pengumpulan Data}

Observasi dilakukan agar memudahkan peneliti menganalisis serta merancang EA di Rumah Sakit. Observasi dilakukan dengan mengamati sekitar Rs. Bhayangkara Setukpa Lemdiklat Polri. Wawancara dilakukan untuk menyelesaikan informasi, mendapatkan informasi dan sumber yang tepat [10]. Wawancara dilakukan kepada beberapa staf di Rumah Sakit untuk mengetahui keadaan yang sedang berjalan saat ini. Hasil wawancara yang di dapat di Rumah Sakit masih kesulitan dalam hal pendaftaran, karena sistem yang ada masih bersifat offline. Sehingga terjadi nya keterlambatan dalam hal menangani pasien berobat jalan. Studi Pustaka dilakukan untuk menangani masalah yang terkait pada penelitian ini dan dari bahan pustaka yang berlaku [11], sehingga dapat membantu alur permasalahan yang ada.

\section{Langkah Penelitian}

Penelitian yang dilakukan adalah merancang EA menggunakan TOGAF ADM. Dalam penelitian ini fase yang akan diambil yaitu: Preliminary Phase, Requirements Management Architecture Vision, Business Architecture, Information Systems Architecture, Technology Architecture, Opportunities and Solutions, Migration Planning dan Implementation Governance.

\section{Hasil dan Pembahasan}

\section{Peliminary Phase}

Pada fase ini terdapat tahapan yang mencakup aktivitas persiapan awal atau pengidentifikasian awal untuk menyusun kapabilitas arsitektur termasuk langkah TOGAF ADM dan COBIT 5.

Goal Cascading

Visi Rs. Bhayangkara Lemdiklat Polri adalah "Terwujudnya Rumah Sakit Bhayangkara Setukpa Lemdiklat Polri Yang Profesional, Modern dan Terpercaya Dalam Memberikan Pelayanan kesehatan". Untuk menyelaraskan teknologi informasi dengan visi rumah sakit perlu dilakukan Goals Cascading sesuai dengan COBIT 5. Berikut hasil pemetaan IT Process terpilih.

Tabel 1. IT Process Terpilih

\begin{tabular}{|c|l|}
\hline Kode & \multicolumn{1}{c|}{ IT Process } \\
\hline EDM03 & Ensure Risk Optimisation \\
\hline DSS05 & Manage Security Service \\
\hline BAI01 & Manage Programmes and Project \\
\hline APO04 & Manage Innovation \\
\hline
\end{tabular}


Herza Martianda ${ }^{1}$, Sudin Saepudin ${ }^{2}$

@ is The Best: Accounting Information Systems and Information Technology Business Enterprise

ISSN: 2252-9853 (Print) | ISSN: 2656-808X (Online)

\begin{tabular}{|l|l|}
\hline APO07 & Manage Human Resource \\
\hline BAI08 & Manage Knowledge \\
\hline BAI06 & Manage Change \\
\hline
\end{tabular}

\section{Principle Catalog}

Tabel 2. Principle Catalog

\begin{tabular}{|c|}
\hline Principle \\
\hline $\begin{array}{c}\text { Architecture Principle : Pernyataan dalam arsitektur harus secara ringkas dan jelas. Pernyataan prinsip harus tidak } \\
\text { ambigu. }\end{array}$ \\
\hline $\begin{array}{c}\text { Business Principle }: \text { Menjalankan bisnis dengan visi rumah sakit seperti rumah sakit yang profesional, modern dan } \\
\text { memberikan pelayanan rumah sakit. }\end{array}$ \\
\hline Data/Information Principle $:$ Data harus dilindungi dari penggunaan yang tidak sah. \\
\hline Application Principle $:$ Pemakaian Aplikasi pendaftaran rawat jalan yang mudah digunakan. \\
\hline Technology Principle $:$ Menggunakan software, hardware dan arsitektur jaringan yang sesuai dengan arsitektur. \\
\hline
\end{tabular}

\section{Requirements Management}

Pada fase ini menentukan kebutuhan proses terhadap perancangan EA di Rumah Sakit. Pada fase ini dibutuhkan aktivitas mencakup kondisi yang sedang berjalan saat ini menggunakan Use Case, Organizations Issues dan rekomendasi solusi aktivitas. Use Case adalah pemodelan dan mendeskripsikan suatu interaksi antara satu atau lebih aktor dengan aplikasi yang akan dibuat [12]. Kondisi Berjalan Di Rumah Sakit Saat Ini.

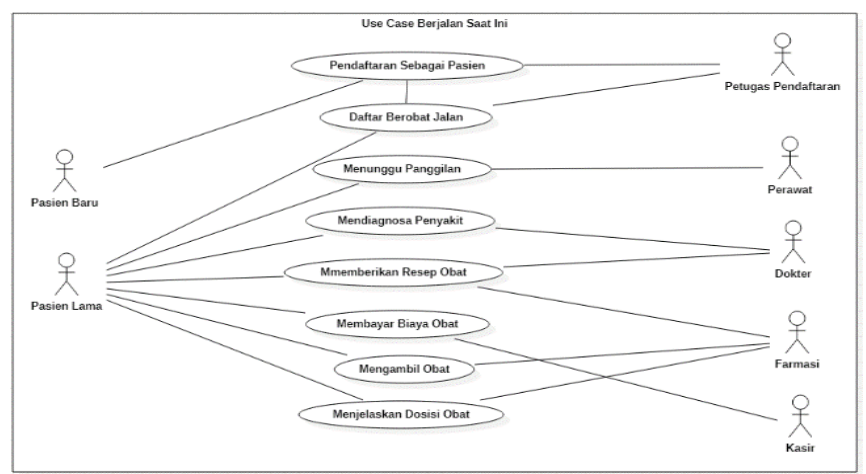

Gambar 5. Use Case Berjalan Saat Ini

Organizations Issues

Business Capability Mapping and Capability Assessment

Tabel 3. Business Capability Mapping and Capability Assessment

\begin{tabular}{|c|l|l|c|}
\hline Capability & \multicolumn{1}{|c|}{ Description } & \multicolumn{1}{c|}{ Performance } & $\begin{array}{c}\text { Capability } \\
\text { Level }\end{array}$ \\
\hline Innovation & $\begin{array}{l}\text { Rumah sakit melakukan inovasi untuk } \\
\text { mencapai keuntungan kompetitif. }\end{array}$ & $\begin{array}{l}\text { Rumah sakit belum sepenuh nya } \\
\text { melakukan inovasi untuk mencapai } \\
\text { keuntungan }\end{array}$ & Level 5 \\
\hline Problem & $\begin{array}{l}\text { Rumah sakit menangani masalah } \\
\text { operasional untuk meningkatkan } \\
\text { layanan bisnis }\end{array}$ & $\begin{array}{l}\text { Rumah sakit belum sepenuhnya } \\
\text { meningkatkan layanan bisnis }\end{array}$ & Level 5 \\
\hline $\begin{array}{c}\text { Business } \\
\text { Process } \\
\text { Controls }\end{array}$ & $\begin{array}{l}\text { Rumah sakit menjaga integritas } \\
\text { informasi aset yang ditangani dalam } \\
\text { proses bisnis nya }\end{array}$ & $\begin{array}{l}\text { Rumah sakit belum sepenuhnya } \\
\text { menjaga integritas informasi }\end{array}$ & Level 5 \\
\hline
\end{tabular}


@is The Best: Accounting Information Systems and Information Technology Business Enterprise

ISSN: 2252-9853 (Print) | ISSN: 2656-808X (Online)

\section{IT Capability}

Tabel 4. IT Capability

\begin{tabular}{|c|c|c|c|}
\hline Domain & Proses & Analisis Maturity Model & Target Arsitektur \\
\hline Bisnis & $\begin{array}{l}\text { EDM } 03 \text { - Ensure } \\
\text { Risk Optimization }\end{array}$ & $\begin{array}{l}\text {-Tidak terdapat alternatif pendaftaran rawat } \\
\text { jalan secara online bila pendaftaran terlalu } \\
\text { banyak antrian. }\end{array}$ & $\begin{array}{l}\text { Level } 5 \text { : Terdapat cadangan } \\
\text { pendaftaran rawat jalan secara } \\
\text { online berupa sistem informasi. }\end{array}$ \\
\hline Data & $\begin{array}{l}\text { DSS05 - Manage } \\
\text { Security Services }\end{array}$ & $\begin{array}{l}\text {-Adanya keamanan sistem akses terhadap } \\
\text { data. } \\
\text {-Tidak terdapat standar yang ketat yang } \\
\text { berkaitan dengan keamanan }\end{array}$ & $\begin{array}{l}\text { Level } 5 \text { : Adanya keamanan } \\
\text { yang berkaitan dengan } \\
\text { penggunaan teknologi. }\end{array}$ \\
\hline Aplikasi & $\begin{array}{lr}\text { BAI01- } & \text { Manage } \\
\text { Programmes } & \text { and } \\
\text { Projects } & \end{array}$ & $\begin{array}{l}\text {-Proyek IT yang saat ini ada masih belum } \\
\text { lengkap, seperti tidak adanya fitur dwonload } \\
\text { terhadap data yang diinput. } \\
\text {-Tidak menggunakan framework manajemen } \\
\text { proyek tertentu dalam mengelola proyek. }\end{array}$ & $\begin{array}{l}\text { Level } 5 \text { : Adanya framework } \\
\text { proyek manajemen dalam } \\
\text { pengelolaan proyek. }\end{array}$ \\
\hline Teknologi & $\begin{array}{l}\text { APO04 - Manage } \\
\text { Innovation }\end{array}$ & -Terdapat akun sosial media. & $\begin{array}{l}\text { Level } 5 \text { : Rumah sakit terus } \\
\text { mengembangkan inovasi. }\end{array}$ \\
\hline SDM & $\begin{array}{l}\text { APO07 - Manage } \\
\text { Human Resources }\end{array}$ & $\begin{array}{l}\text {-Pegawai IT hanya beranggotakan dua orang } \\
\text { saja. }\end{array}$ & $\begin{array}{l}\text { Level } 5 \text { : Perlunya perekrutan } \\
\text { SDM pada IT untuk } \\
\text { mendukung } \\
\text { Architecture. }\end{array}$ \\
\hline Pengetahuan & $\begin{array}{l}\text { BAI08 - Manage } \\
\text { Knowledge }\end{array}$ & -Pegawai kurang memahami IT saat ini. & $\begin{array}{l}\text { Level } 5 \text { : } \text { Perlunya pelatihan } \\
\text { terhadap IT yang akan } \\
\text { dijalankan. }\end{array}$ \\
\hline
\end{tabular}

Solusi Aktivitas

Tabel 5. Solusi Aktivitas

\begin{tabular}{|l|l|}
\hline \multicolumn{1}{|c|}{ Aktivitas } & \multicolumn{1}{|c|}{ Solusi Aktivitas } \\
\hline Pendaftaran Rawat Jalan & $\begin{array}{l}\text { Penyediaan sistem informasi untuk pendaftaran rawat jalan secara online yang } \\
\text { terintegrasi. }\end{array}$ \\
\hline SDM terhadap IT & Perekrutan karyawan di bidang IT. \\
\hline Pengetahuan Karyawan & Perlu diadakan nya pelatihan karyawan terhadap TI. \\
\hline $\begin{array}{l}\text { Teknologi keperluan } \\
\text { bisnis }\end{array}$ & $\begin{array}{l}\text { Tambahkan sosial media, ubah dan tambah kebutuhan software, hardware, dan arsitektur } \\
\text { jaringan. }\end{array}$ \\
\hline
\end{tabular}

\section{Architecture Vision}

Pada fase ini mendefinisikan Value Chain Analysis untuk proses bisnis yang ada di rumah sakit pada aktivitas utama dan aktivitas pendukung Aktivitas. Tujuan dari Value Chain adalah mendapatkan margin dari semua aktivitas yang akan dilakukan.

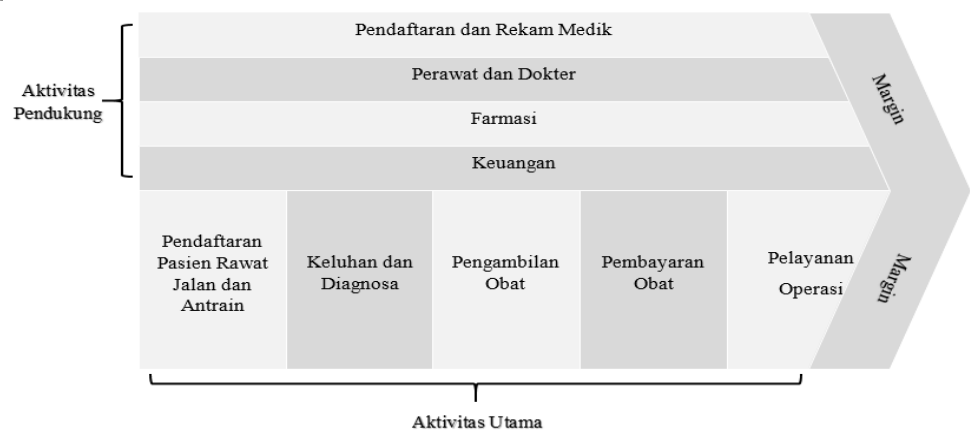

\section{Business Architecture}

Gambar 6. Value Chain Analysis

Pada business architecture berisi tentang alur aktivitas yang diusulkan dengan kebutuhan di Rumah Sakit. 
Herza Martianda ${ }^{1}$, Sudin Saepudin ${ }^{2}$

@ is The Best: Accounting Information Systems and Information Technology Business Enterprise ISSN: 2252-9853 (Print) | ISSN: 2656-808X (Online)

\section{Use Case Diagram Pasien}

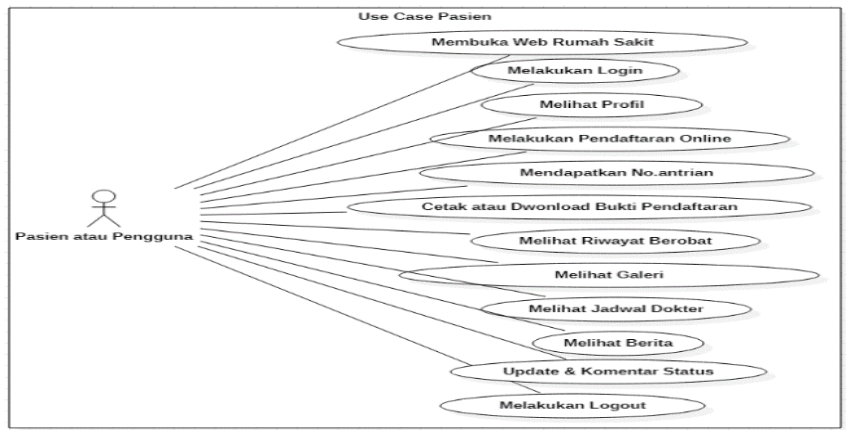

Gambar 7. Use Case Pasien

Use Case Diagram Admin Pendaftaran

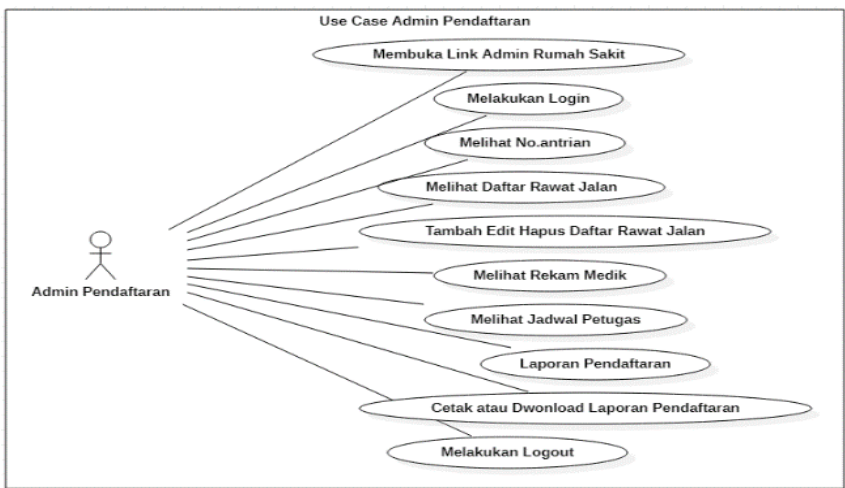

Gambar 8. Use Case Admin Pendaftaran

Use Case Diagram Admin Perawat

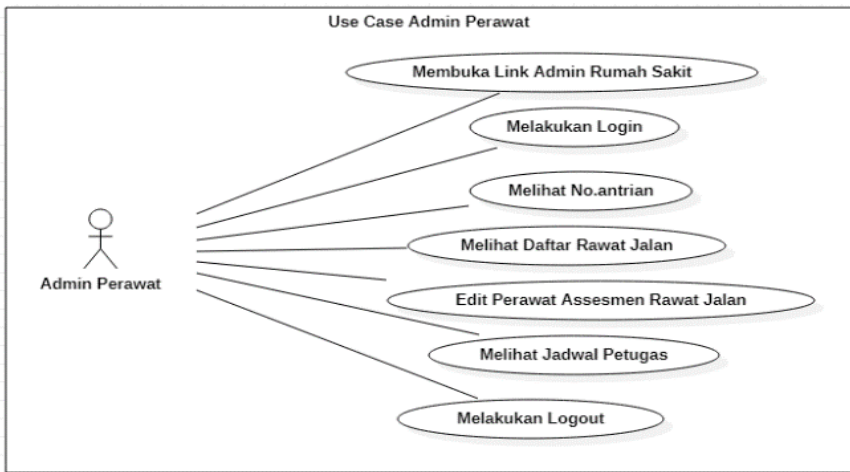

Gambar 9. Use Case Admin Perawat

Use Case Diagram Admin Dokter

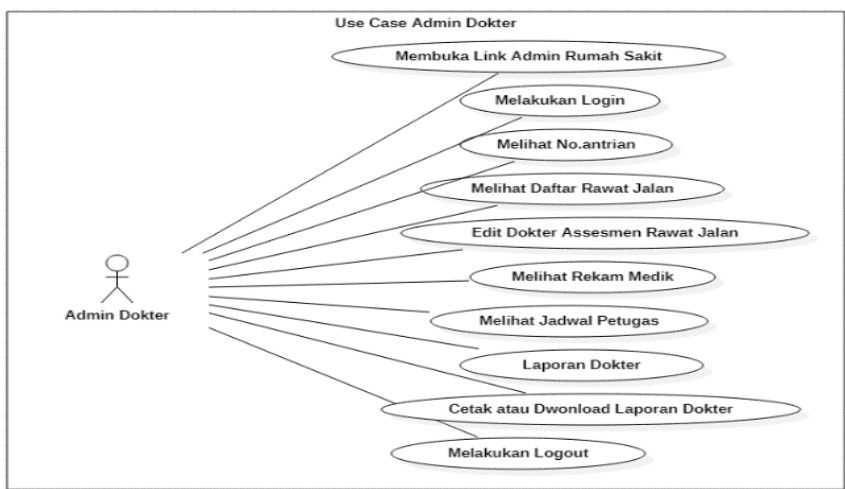

Gambar 10. Use Case Admin Dokter 
Use Case Diagram Admin Farmasi

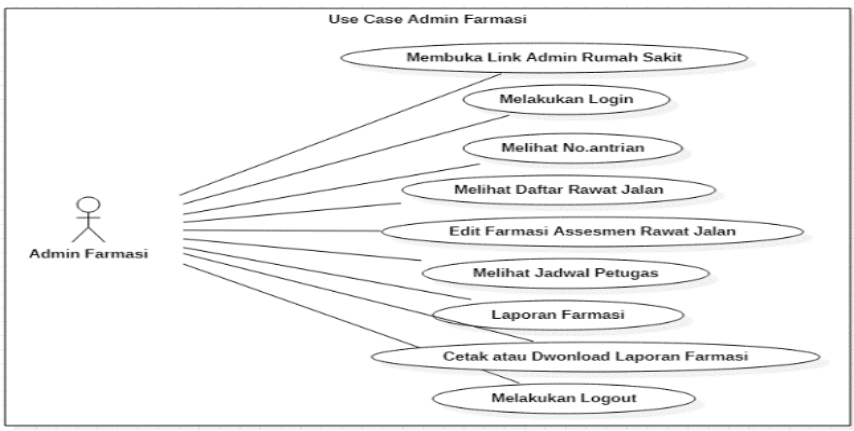

Gambar 11. Use Case Admin Farmasi

Use Case Diagram Admin Kasir

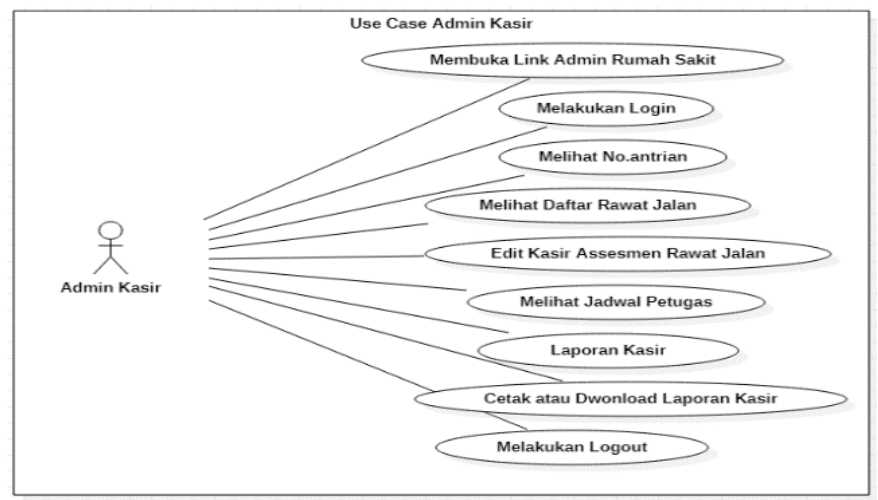

Gambar 12. Use Case Admin Kasir

Use Case Diagram Admin Rekam Medik

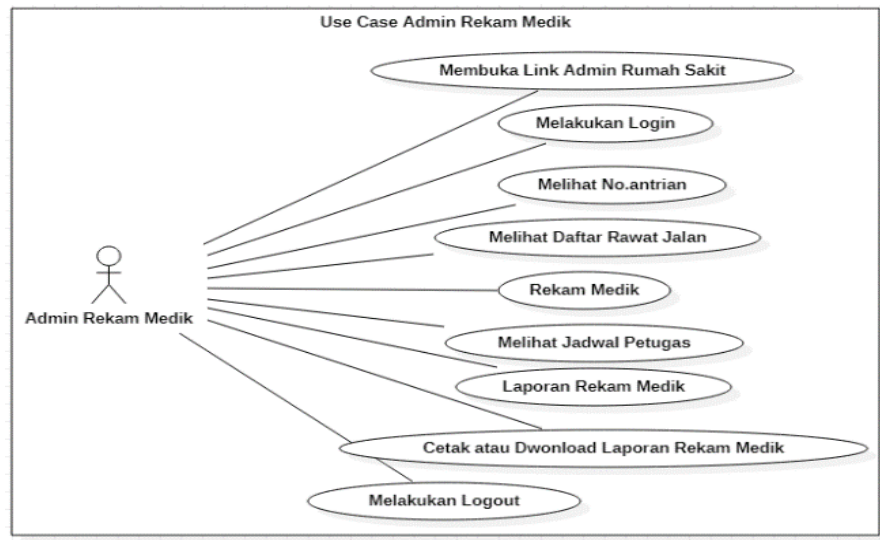

Gambar 13. Use Case Admin Rekam Medik

\section{Information System Architectures}

Fase ini melibatkan antara arsitektur data dan juga arsitektur teknologi/aplikasi. Fase ini berpusat pada sistem informasi yang akan dikembangkan pada data yang terintegrasi. 
Arsitektur Data

Activity Diagram Berobat Jalan

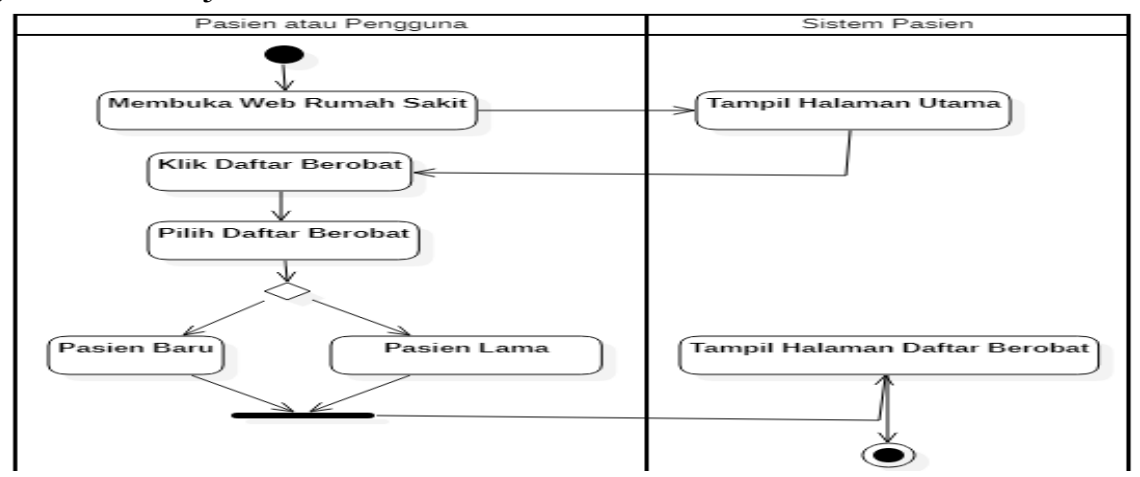

Gambar 14. Activity Diagram Berobat Jalan

Activity Diagram Pasien Baru

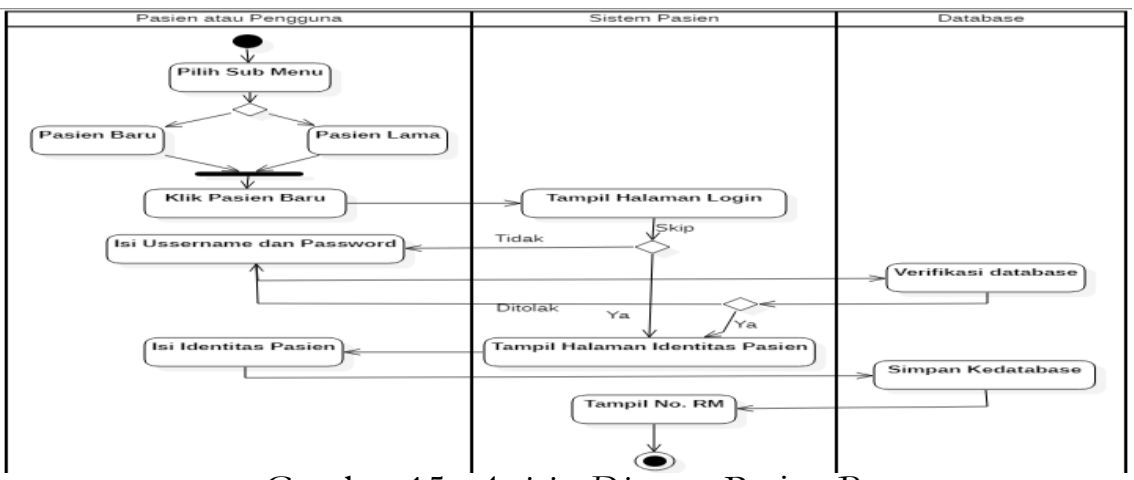

Gambar 15. Activity Diagram Pasien Baru

Activity Diagram Pasien Lama

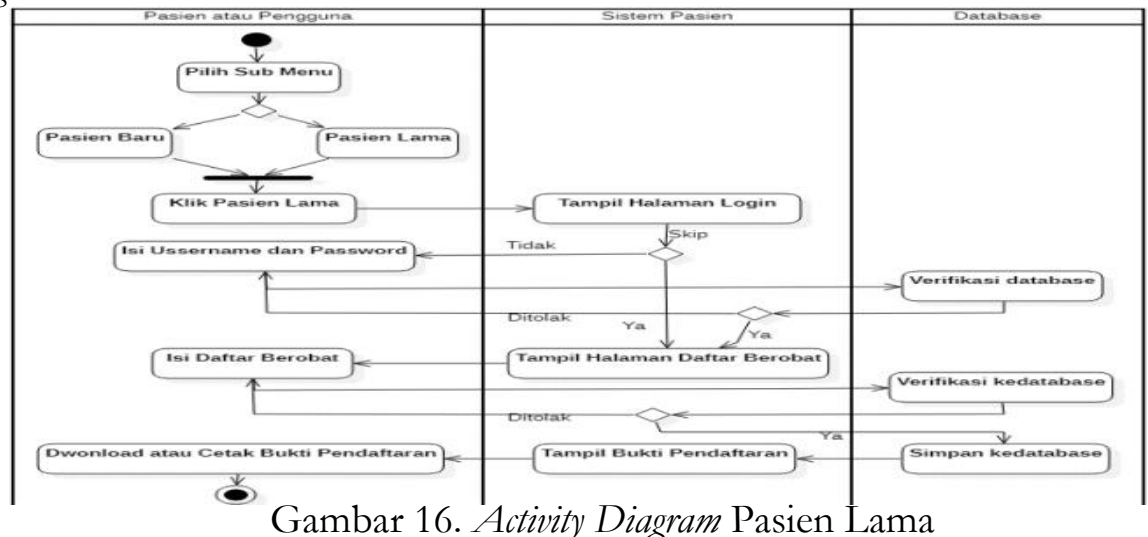


Herza Martianda ${ }^{1}$, Sudin Saepudin ${ }^{2}$

@ is The Best: Accounting Information Systems and Information Technology Business Enterprise ISSN: 2252-9853 (Print) | ISSN: 2656-808X (Online)

Activity Diagram Login Pasien

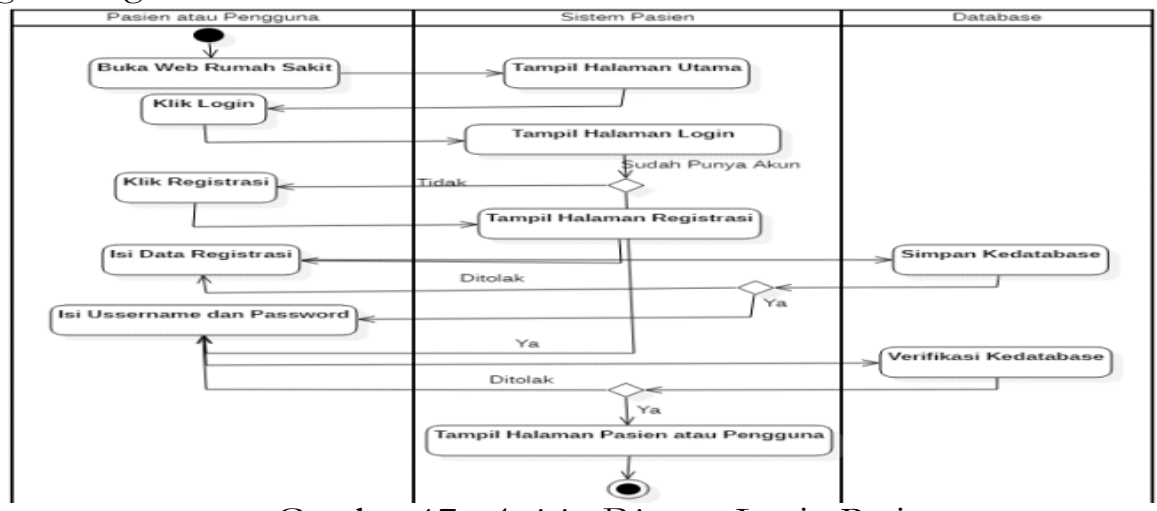

Gambar 17. Activity Diagram Login Pasien

Activity Diagram Admin Pendaftaran

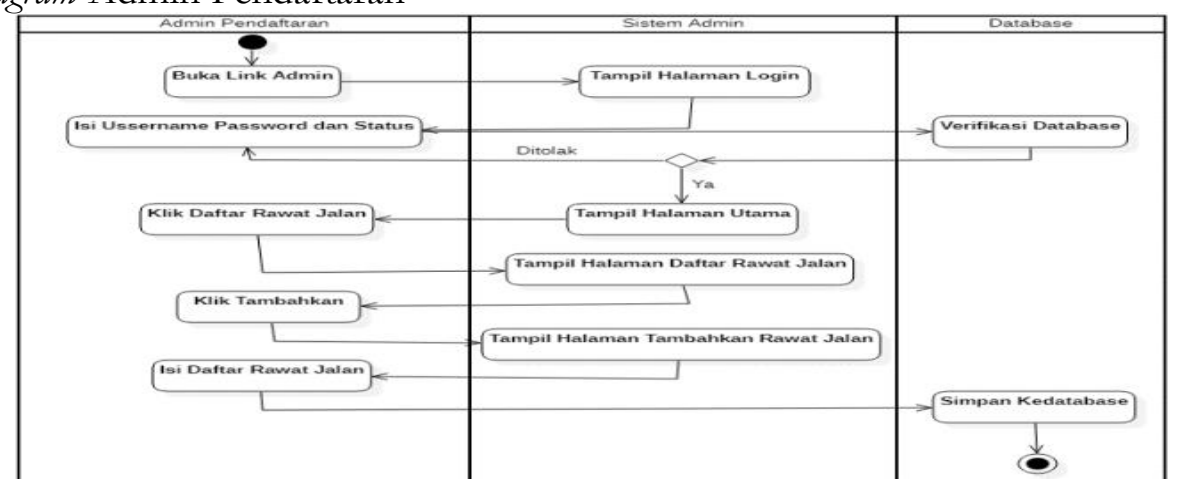

Gambar 18. Activity Diagram Admin Pendaftaran

Activity Diagram Admin Perawat

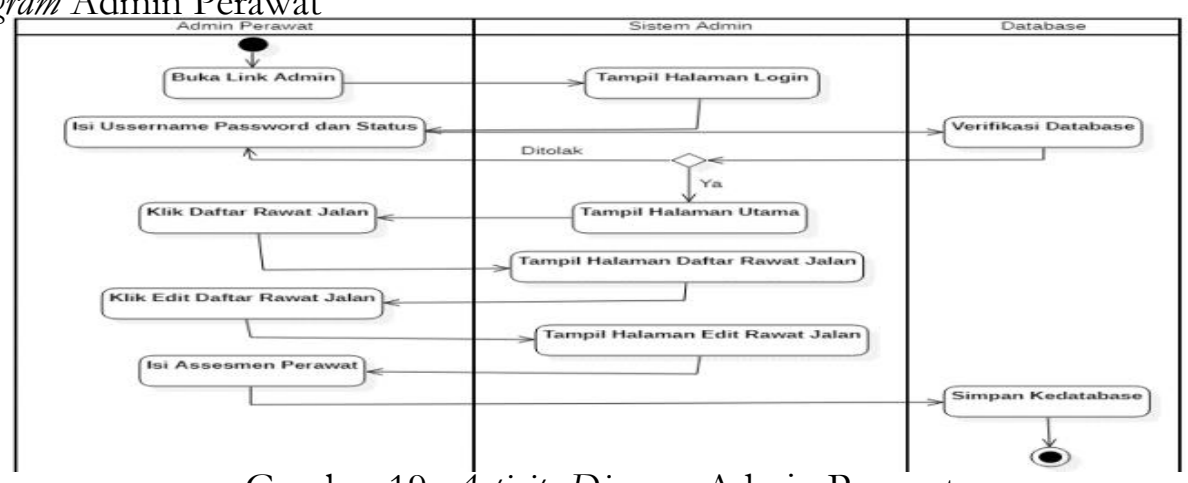

Gambar 19. Activity Diagram Admin Perawat

Activity Diagram Admin Dokter

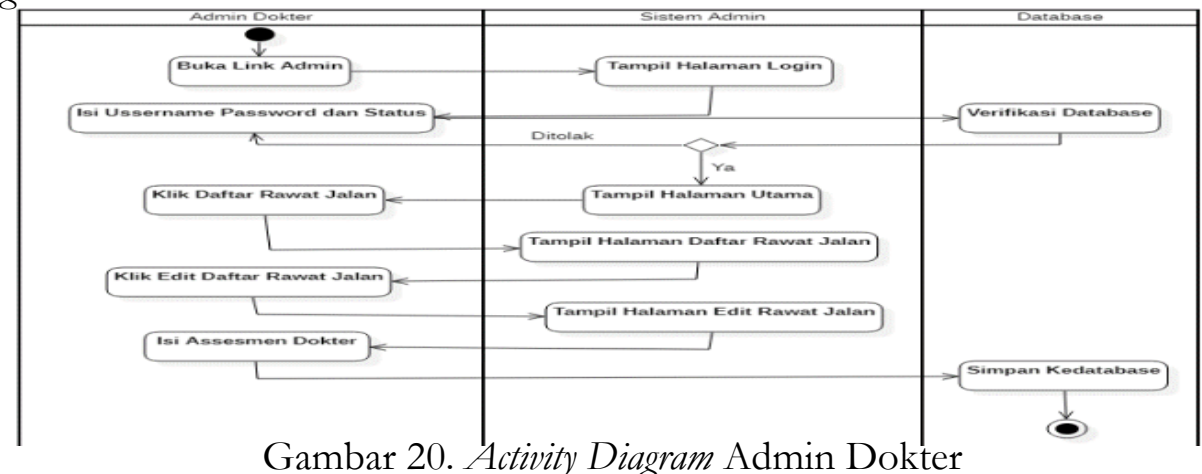

Volume 6 Nomor 1 (2021) Hal. 46-60 
Herza Martianda ${ }^{1}$, Sudin Saepudin ${ }^{2}$

@ is The Best: Accounting Information Systems and Information Technology Business Enterprise ISSN: 2252-9853 (Print) | ISSN: 2656-808X (Online)

Activity Diagram Admin Farmasi

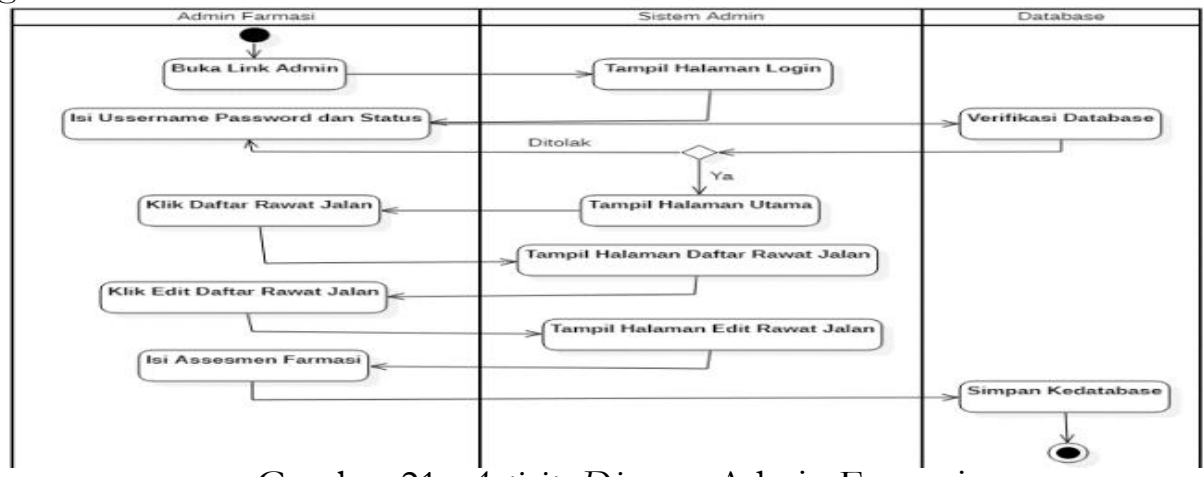

Gambar 21. Activity Diagram Admin Farmasi

Activity Diagram Admin Kasir

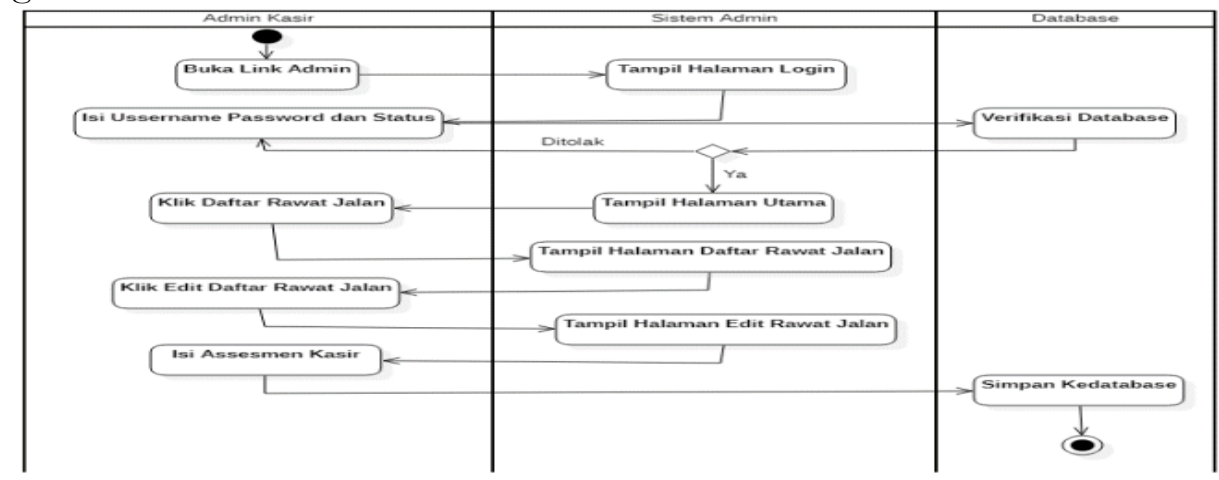

Gambar 22. Activity Diagram Admin Kasir

Activity Diagram Admin Rekam Medik

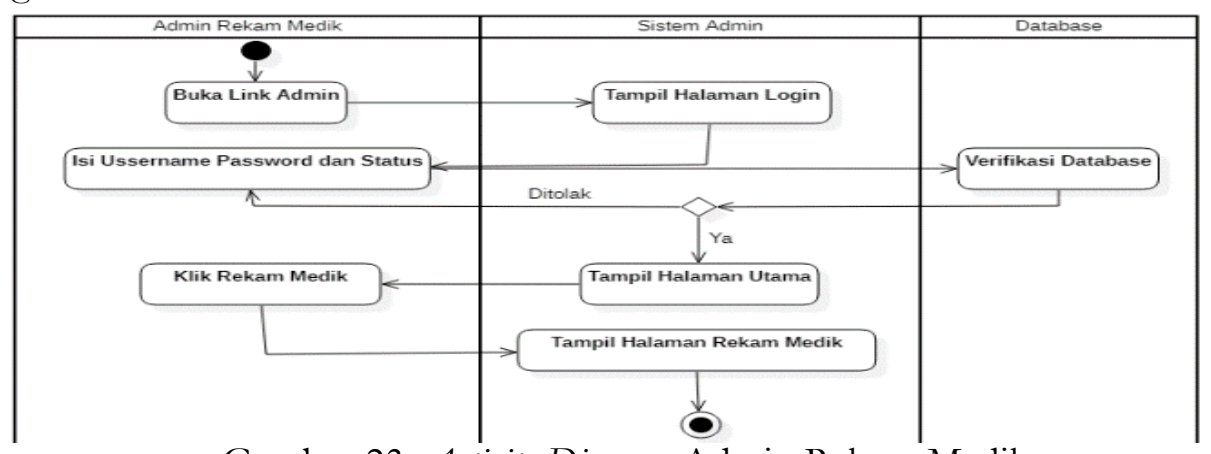

Gambar 23. Activity Diagram Admin Rekam Medik

Database atau Basis Data

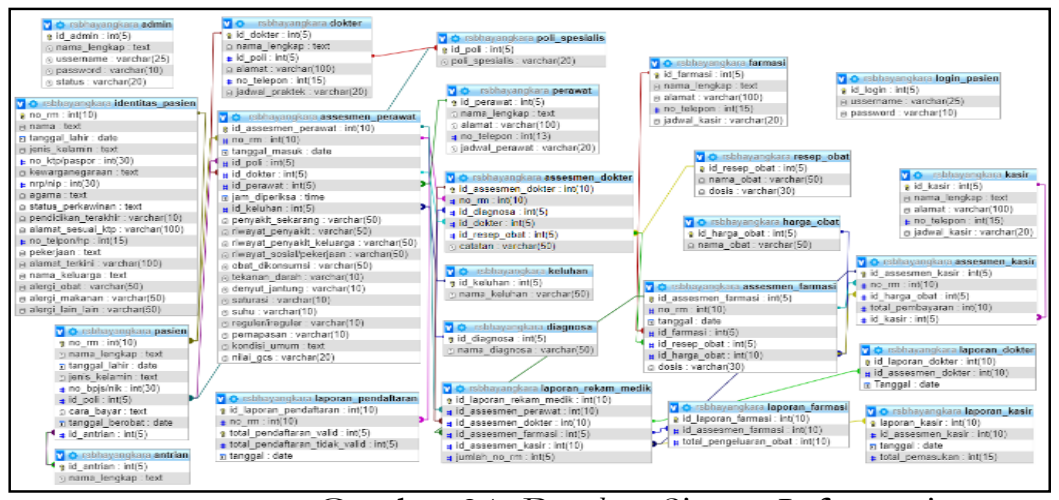

Gambar 24. Database Sistem Informasi

Volume 6 Nomor 1 (2021) Hal. 46-60 
@is The Best: Accounting Information Systems and Information Technology Business Enterprise

ISSN: 2252-9853 (Print) | ISSN: 2656-808X (Online)

Arsitektur Aplikasi

Pada fase ini menjabarkan sistem aplikasi di Rumah Sakit yang nanti nya akan melakukan proses. Berikut adalah desain katalog aplikasi pasien / pengguna dan admin yang akan dibuat:

Tabel 6. Desain Katalog Aplikasi Pasien

\begin{tabular}{|l|l|}
\hline \multicolumn{1}{|c|}{ Nama Proses } & \multicolumn{1}{c|}{ Keterangan } \\
\hline $\begin{array}{l}\text { Pendaftaran Berobat } \\
\text { Pasien Baru }\end{array}$ & $\begin{array}{l}\text { Pengguna atau pasien baru yang belum mempunyai No. RM, bisa melakukan } \\
\text { pendaftaran dengan mengisi formulir yang sudah ada di sistem untuk memberikan } \\
\text { identitas. Setelah mengisi identitas akan langsung masuk ke pendaftaran berobat jalan. }\end{array}$ \\
\hline $\begin{array}{l}\text { Pendaftaran Berobat } \\
\text { Pasien Lama }\end{array}$ & $\begin{array}{l}\text { Pengguna atau pasien lama mengisi formulir yang sudah ada di sistem untuk memproses } \\
\text { antrian berobat jalan. }\end{array}$ \\
\hline Login/Registrasi & Pengguna bisa melakukan login untuk melihat riwayat berobat dan melakukan registrasi. \\
\hline Riwayat Berobat & Pengguna atau pasien bisa melakukan perubahan di menu riwayat berobat. \\
\hline
\end{tabular}

Tabel 7. Desain Katalog Aplikasi Admin

\begin{tabular}{|c|c|}
\hline Nama Proses & Keterangan \\
\hline \multicolumn{2}{|l|}{ Admin Pendaftaran } \\
\hline Login & Admin pendaftaran melakukan login dengan memasukkan username, password dan status. \\
\hline Daftar Rawat Jalan & Admin pendaftaran bisa menambahkan daftar pasien rawat jalan, mengedit dan menghapus \\
\hline \multicolumn{2}{|l|}{ Admin Perawat } \\
\hline Login & Admin Perawat melakukan login dengan memasukkan username, password dan status. \\
\hline Daftar Rawat Jalan & Mengedit assessment perawat. \\
\hline \multicolumn{2}{|l|}{ Admin Dokter } \\
\hline Login & Admin Dokter melakukan login dengan memasukkan username, password dan status. \\
\hline Daftar Rawat Jalan & Mengedit assessment dokter. \\
\hline \multicolumn{2}{|l|}{ Admin Farmasi } \\
\hline Login & Admin Farmasi melakukan login dengan memasukkan username, password dan status. \\
\hline Daftar Rawat Jalan & Mengedit assessment farmasi. \\
\hline \multicolumn{2}{|l|}{ Admin Kasir } \\
\hline Login & Admin Kasir melakukan login dengan memasukkan username, password dan status. \\
\hline Daftar Rawat Jalan & Mengedit assessment kasir. \\
\hline
\end{tabular}

\section{Technology Architecture}

Pada fase ini memetakan komponen aplikasi yang sebelumnya sudah dijelaskan di arsitektur aplikasi kedalam satu komponen teknologi yaitu software (Perangkat Lunak), hardware (Perangkat Keras) dan arsitektur jaringan.

Software dan Hardware

Tabel 8. Usulan Software dan Hardware

\begin{tabular}{|l|l|l|l|}
\hline Software & Operating System (OS) & Spesifikasi & Microsoft Windows 10 \\
\hline & Web Browser & & Google Chrome \\
\hline & DBMS & MYSQL \\
\hline & Pemrograman & JavaScript, PHP \\
\hline & Microsoft Office & 2019 \\
\hline \multirow{2}{*}{ Hardware } & Processor & Spesifikasi & $\begin{array}{l}\text { Intel } \mathbb{R} \text { CoreTM i3-8130U Processor (2.20 GHz, up to } \\
\text { 3.40 GHz. 4M Cache) }\end{array}$ \\
\hline & Memory & & 4GB RAM \\
\hline & Hard Drive & 1TB HDD \\
\hline & Keyboard & Wired Keyboard \\
\hline & Ragam Input Device & Wired Mouse \\
\hline
\end{tabular}


Arsitektur Jaringan

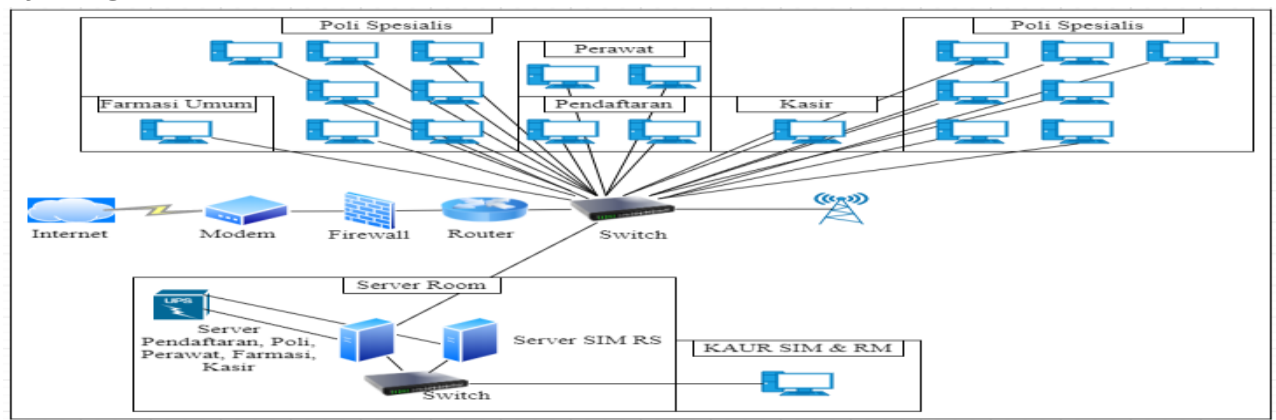

Gambar 25. Usulan Arsitektur Jaringan

\section{Opportunities and Solutions}

Analisis SWOT adalah penilaian terhadap hasil identifikasi situasi, untuk menentukan suatu kondisi dikategorikan sebagai kekuatan, kelemahan, peluang ataupun ancaman[13].

Strength dari sistem informasi pendaftaran rawat jalan secara online adalah sistem informasi ini dapat membantu pasien dan karyawan dalam mengatasi pendaftaran rawat jalan. Strength dari SDM IT adalah dengan melakukan perekrutan karyawan bagi manajemen IT dapat membantu strategi bisnis atau mengelola dan menyelaraskan bisnis dengan IT dirumah sakit, karena manajemen IT tidak cukup dua orang saja. Strength pada pengetahuan karyawan terhadap IT dapat membantu proses bisnis yang ada di rumah sakit menjadi lebih efektif dan efisien. Strength pada kebutuhan teknologi adalah untuk meningkatkan pemasaran di rumah sakit, karena dirumah sakit juga perlu pemasaran agar jumlah pengunjung rawat jalan dapat bertambah dan meningkatkan kualitas teknologi agar dapat berjalan dengan baik.

Weakness pada sistem informasi pendaftaran secara online adalah sistem masih terbatas pada penyediaan informasi layanan seperti jumlah antrian yang saat ini sedang berjalan bisa saja tidak valid jika pengguna atau pasien mengganti-ganti jadwal berobat yang sudah direncanakan. Selain itu jadwal dokter bisa berubah-ubah tergantung bagaimana rumah sakit cepat tanggap dalam melakukan perubahan. SDM IT pun tentu ada Weakness nya, dengan perekrutan SDM IT yang bukan ahlinya atau kurang menguasai perkembangan IT dapat menjadi kelemahan Rumah Sakit. Pengetahuan karyawan setelah diadakannya pelatihan belum tentu semua karyawan mengerti apa yang sudah didefinisikan. Kelemahan terhadap pengetahuan karyawan dapat memperlambat proses bisnis Rumah Sakit. Weakness pada kebutuhan teknologi adalah dapat penyalahgunaan untuk pencurian data, bisa saja rumah sakit terjerumus dalam tindakan pencurian data. Maka rumah sakit perlu meningkatkan keamanan terhadap teknologi.

Opportunities terhadap sistem informasi pendaftaran rawat jalan secara online adalah belum adanya persaingan sistem informasi pendaftaran secara online di area sukabumi. Hal ini dapat meningkatkan daya tarik masyarakat atau pasien untuk berobat di Rs. Setukpa Lemdiklat Polri, karena dengan adanya sistem informasi dapat lebih cepat untuk berobat jalan. Opportunities terhadap SDM IT adalah dengan adanya SDM IT baru dapat menentukan inovasi atau strategi yang baru, sehingga Rumah Sakit dapat bertahan di era yang serba teknologi saat ini.

Perkembangan teknologi yang cepat dan berubah-ubah dapat menyebabkan keterlambatan dalam mengadopsinya. Selain itu strategi pesaing yang berubah dapat mengancam posisi di rumah sakit. Maka IT harus cepat tanggap dalam kemajuan teknologi-teknologi yang baru.

\section{Migration Planning}

Fase Migration Planning atau rencana migrasi adalah rencana implementasi dan migrasi yang tepat. 
@ is The Best: Accounting Information Systems and Information Technology Business Enterprise

ISSN: 2252-9853 (Print) | ISSN: 2656-808X (Online)

Tabel 9. Rencana Migrasi

\begin{tabular}{|l|c|c|c|c|c|c|}
\hline \multicolumn{2}{|c|}{ Nama Aktivitas } & \multicolumn{5}{c|}{ Jadwal } \\
\cline { 2 - 7 } & B-1 & B-3 & B-7 & B-8 & B-9 & B-10 \\
\hline Perekrutan SDM TI & & & & & & \\
\hline Pembuatan Sistem Informasi Pendaftaran & & & & & & \\
\hline Backup sistem lama dan aktivitas sistem baru & & & & & & \\
\hline Pelatihan karyawan terhadap TI dan sistem informasi & & & & & & \\
\hline Pemasaran di akun sosial media & & & & & & \\
\hline Merekayasa ulang teknologi lama ke teknologi baru & & & & & & \\
\hline
\end{tabular}

\section{Implementation Governance}

Fase ini dilakukan untuk menyusun pelaksanaan tata kelola teknologi yang sebelumnya sudah dibahas di Requirements Management secara terstruktur. Pelaksanaan tata kelola ini sesuai dengan pendekatan kedua Framework. TOGAF ADM dan COBIT 5. Assessment usulan yang akan digunakan oleh COBIT 5 terhadap proses teknologi informasi melalui Capability Level. Hal ini digunakan untuk melakukan audit setelah dilakukan implementasi dan untuk menjembatangani kesenjangan antara baseline dan target yang akan dicapai. Target Capability Level pada setiap proses dijabarkan berikut ini:

Tabel 10. Target Capability Level

\begin{tabular}{|c|c|c|c|c|c|c|c|c|c|c|}
\hline \multirow{2}{*}{$\begin{array}{c}\text { Capability } \\
\text { Level }\end{array}$} & \multirow[t]{2}{*}{ Level 0} & \multirow{2}{*}{$\begin{array}{c}\text { Level 1 } \\
\text { PA 1.1 } \\
\end{array}$} & \multicolumn{2}{|c|}{ Level 2} & \multicolumn{2}{|c|}{ Level 3} & \multicolumn{2}{|c|}{ Level 4} & \multicolumn{2}{|c|}{ Level 5} \\
\hline & & & PA 2.1 & PA 2.2 & PA 3.1 & PA 3.2 & PA 4.1 & PA 4.2 & PA 5.1 & PA 5.2 \\
\hline \multicolumn{11}{|c|}{ EDM03 - Ensure Risk Optimization } \\
\hline \multirow{2}{*}{ Target Rating } & & $100 \%$ & $100 \%$ & $100 \%$ & $100 \%$ & $100 \%$ & $100 \%$ & $100 \%$ & $100 \%$ & $100 \%$ \\
\hline & & F & F & $\mathrm{F}$ & $\mathrm{F}$ & F & F & F & F & $\mathrm{F}$ \\
\hline \multicolumn{11}{|c|}{ DSS05 - Manage Security Services } \\
\hline \multirow{2}{*}{ Target Rating } & & $100 \%$ & $100 \%$ & $100 \%$ & $100 \%$ & $100 \%$ & $100 \%$ & $100 \%$ & $100 \%$ & $100 \%$ \\
\hline & & $\mathrm{F}$ & $\mathrm{F}$ & $\mathrm{F}$ & $\mathrm{F}$ & $\mathrm{F}$ & $\mathrm{F}$ & $\mathrm{F}$ & $\mathrm{F}$ & $\mathrm{F}$ \\
\hline \multicolumn{11}{|c|}{ BAI01 - Manage Programmes and Projects } \\
\hline \multirow{2}{*}{ Target Rating } & & $100 \%$ & $100 \%$ & $100 \%$ & $100 \%$ & $100 \%$ & $100 \%$ & $100 \%$ & $100 \%$ & $100 \%$ \\
\hline & & F & F & F & F & F & F & F & F & F \\
\hline \multicolumn{11}{|c|}{ APO04 - Manage Innovation } \\
\hline \multirow{2}{*}{ Target Rating } & & $100 \%$ & $100 \%$ & $100 \%$ & $100 \%$ & $100 \%$ & $100 \%$ & $100 \%$ & $100 \%$ & $100 \%$ \\
\hline & & $\mathrm{F}$ & F & $\mathrm{F}$ & $\mathrm{F}$ & F & F & F & F & F \\
\hline \multicolumn{11}{|c|}{ APO07 - Manage Human Resources } \\
\hline \multirow{2}{*}{ Target Rating } & & $100 \%$ & $100 \%$ & $100 \%$ & $100 \%$ & $100 \%$ & $100 \%$ & $100 \%$ & $100 \%$ & $100 \%$ \\
\hline & & $\mathrm{F}$ & $\mathrm{F}$ & $\mathrm{F}$ & $\mathrm{F}$ & F & $\mathrm{F}$ & F & F & F \\
\hline \multicolumn{11}{|c|}{ BAI08 - Manage Knowledge } \\
\hline \multirow{2}{*}{ Target Rating } & & $100 \%$ & $100 \%$ & $100 \%$ & $100 \%$ & $100 \%$ & $100 \%$ & $100 \%$ & $100 \%$ & $100 \%$ \\
\hline & & $\mathrm{F}$ & $\mathrm{F}$ & $\mathrm{F}$ & $\mathrm{F}$ & $\mathrm{F}$ & $\mathrm{F}$ & $\mathrm{F}$ & $\bar{F}$ & $\mathrm{~F}$ \\
\hline
\end{tabular}

\section{Blue Print Perancangan Enterprise Architecture (EA)}

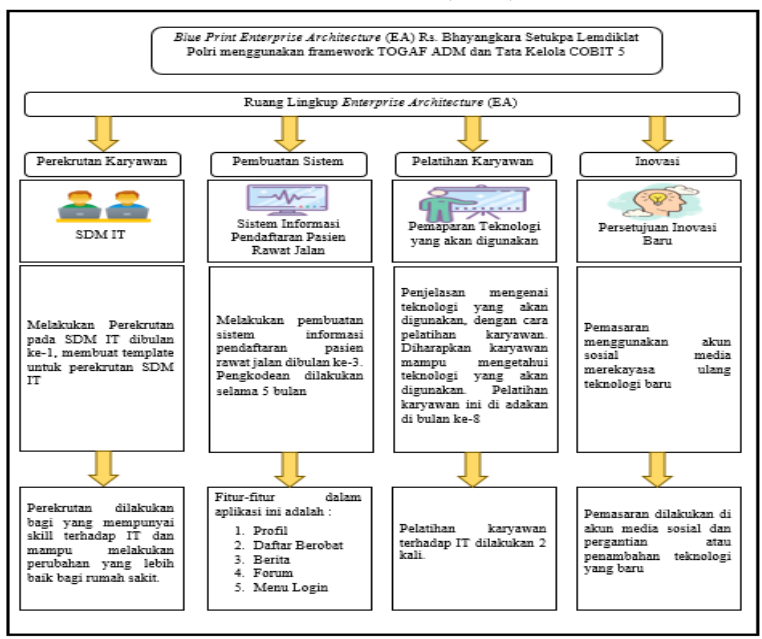

Gambar 26. Blue Print Perancangan EA 


\section{Penutup}

Berdasarkan analisis yang dilakukan pada proses bisnis di RS. Bhayangkara Setukpa Lemdiklat Polri, dapat diambil simpulan, melalui perancangan Enterprise Architecture RS. Bhayangkara Setukpa Lemdiklat Polri mempunyai arsitektur sistem informasi yang menggabungkan antara bisnis dan juga teknologi, sehingga kinerja pelayanan dalam rumah sakit dapat lebih efektif dan juga efisien. Tata kelola teknologi menggunakan COBIT 5 RS. Bhayangkara Setukpa Lemdiklat Polri dapat menjembatangani antara baseline dan target yang akan dicapai. Hasil dari kerangka kerja TOGAF ADM dan Kombinasi COBIT 5 adalah blue print perancangan EA berupa rekomendasi Perekrutan SDM IT, Perancangan Sistem Informasi Pendaftaran Rawat Jalan, Pelatihan karyawan, dan inovasi Pemasaran Pendaftaran Rawat Jalan. Adapun rekomendasi dalam perancangan sistem informasi berupa Usecase diagram, Activity Diagram, Database, Rekomendasi Software, Hardware dan Arsitektur Jaringan di Rs. Bhayangkara Setukpa Lemdiklat Polri.

\section{Daftar Pustaka}

[1] R. F. Awaludin, S. Bahri, dan M. Muslih, "Penerapan Zachman Framework Dalam Perancangan Sistem Informasi Manajemen Keuangan Sekolah ( Studi Kasus: Sd Islam Terpadu Andalusia Kota Sukabumi )," vol. 6, no. 1, 2021.

[2] L. Retnawati, "Perancangan Enterprise Architecture Menggunakan TOGAF di Universitas ABC,” J. IPTEK, vol. 22, no. 1, hal. 13, 2018, doi: 10.31284/j.iptek.2018.v22i1.221.

[3] Kemenkes RI Nomor 340, "KMK No. 340 ttg Klasifikasi Rumah Sakit," Peraturan Menteri Kesehatan Republik Indonesia Nomor 340/MENKES/PER/III/2010. hal. 116, 2010.

[4] Lestari, "Analisis Tingkat Kepuasan Pasien Rawat Jalan (Studi Kasus pada Pasien Rawat Jalan di RSUD Dr. M. Ashari Kabupaten Pemalang," Artik. Ilm. Fak. Ilmu Sos. dan Ilmu Polit. Univ. Diponegoro, vol. 33, hal. 1-12, 2017.

[5] Suryadi dan J. F. Andry, "Perancangan Enterprise Architecture Mengunakan TOGAF Architecture Development Method (Studi Kasus: Yakuza Gym Jakarta Barat)," Semin. Nas. TEKNOKA, vol. 2, no. 2502, hal. 129-134, 2017.

[6] Annisah, "USULAN PERENCANAAN SMART CITY: SMART GOVERNANCE PEMERINTAH DAERAH KABUPATEN MUKOMUKO * Smart City Planning Proposal: Smart Governance for Regional Government of Mukomuko Regency," J. Masy. Telemat. dan Inf., vol. 8 No.1, hal. 59-80, 2017.

[7] A. Supriatna, "Analisa Penerapan Togaf Dan Cobit Dalam Tata Kelola Teknologi Informasi Sebagai Usulan Pada Kementerian Energi Dan Sumber Daya Mineral," Semin. Nas. Inform., vol. 2010, no. semnasIF, hal. 1-8, 2010.

[8] R. Weisman, “An Overview of TOGAF Version 9.1,” Publ. by Open Gr., hal. 43, 2011.

[9] ISACA, Enabling Processes. 2012.

[10] D. Prasanti, "Penggunaan Media Komunikasi Bagi Remaja Perempuan Dalam Pencarian Informasi Kesehatan," LONTAR J. Ilmu Komun., vol. 6, no. 1, hal. 13-21, 2018, doi: 10.30656/lontar.v6i1.645.

[11] M. Sari dan Asmendri, "Penelitian Kepustakaan (Library Research) dalam Penelitian Pendidikan IPA," Penelit. Kepustakaan (Library Res. dalam Penelit. Pendidik. IPA, vol. 2, no. 1, hal. 15, 2018.

[12] E. S. Andani, M. Informatika, dan U. T. Sumbawa, "SISTEM INFORMASI ADMINISTRASI AKADEMIK PADA BIMBINGAN BELAJAR BERBASIS WEB ( STUDI KASUS DILA SAMAWA ) Dosen Informatika, Universitas Teknologi Sumbawa Rodianto@uts.ac.id „2 Evasapitri751@gmail.com Abstrak,”vol. 1, no. 1, hal. 1-10, 2019.

[13] I. Andriyanto, "Analisis SWOT dalam Pengembangan Bisnis ( Studi pada Sentra Jenang di Desa Wisata Kaliputu Kudus ),” vol. 5, no. 2, hal. 363-382. 